known whose atomic environment bears any resemblance to that in the cyclol fabric, any such prediction seems dangerous. In point of fact, the nearest analogues to the eyclol $=\mathrm{C}-\mathrm{OH}$ groups seem to be those in the 1,3,5-trimethyl-2-phenyl (or alkyl)-2-hydroxy-4, 6-dioxohexahydrotriazines recently synthesized ${ }^{11}$. These compounds, it was found, are inert towards diazomethane and phenylisocyanate. These facts, inter alia, show that it cannot be dogmatically asserted that the cyclol $\mathrm{OH}$ groups, if present, would respond to the reagents listed above. In consequence, the negative findings under discussion go no way at all to proving the non-existence of the special type of skeletal $\mathrm{OH}$ groups postulated on the cyclol hypothesis.

Implicit in much of the criticism directed against the cyclol hypothesis is the curious argument that the fact that the eyclol structures contain features new to organic chemistry in itself constitutes evidence against the hypothesis ${ }^{4}$. This fact necessarily makes it difficult and probably impossible to test the hypothesis by such techniques as methylation and acetylation, even if difficulties relating to denaturation prove surmountable. However, since proteins have not yet been synthesized, and since they constitute a class of compounds which in many respects has unique qualities, the argument seems (if significant at all) to be in favour of the hypothesis. Failure to synthesize what have been called "simple substances with cyclol structure" ${ }_{4}$ (a phrase which may prove to be a contradiction in terms) is also no evidence against the hypothesis. Criticisms of this type overlook the fact that all known proteins having molecular status contain thousands of atoms per molecule, and are by no means restricted in their constituents to one or two types of amino acids.

It appears then that the criticisms discussed above - in particular the five experiments - provide no evidence against the cyclol hypothesis. No statement of the case for the hypothesis is necessary, since an authoritative account ${ }^{12}$ has already been given of the way in which it satisfactorily explains many of the well-known properties of the native proteins.

Chemistry Department,

Johns Hopkins University, Baltimore,

Maryland, Feb. 25.

${ }^{1}$ Kellner, Nature, 140, 193 (1937).

2 Wrinch, NATURE, 137, 411 (1936) et seq. Proc. Roy. Soc., A, 160, $59(1937)$, et seq.

s Jenkins and Taylor, J. Chem. Soc., 495 (1937).

4 Pauling and Niemann, J. Amer. Chem. Soc., 61, 1860 (1939).

${ }^{5}$ Bergmann and Niemann, Ann. Rev. Biochem., 7, 110 (1938).

${ }^{6}$ Meyer and Hohenemser, NATURE, 141, 1138 (1938).

' Haurowitz and Astrup, NATURE, 143, 118 (1939).

${ }^{8}$ Holliday, Nature, 143, 895 (1939).

- Wrinch, Phil. Mag., 25, 705 (1938).

${ }^{10}$ Haurowitz, Z. physiol. Chem., 256, 28 (1938).

1I Sobotka and Block, J. Amer. Chem. Soc., 59, 2606 (1937).

12 Langmuir, Proc. Phys. Soc., 51, 542 (1939).

\section{Demonstration of Thermal Diffusion in Liquids}

CONSIDERABLE attention has recently been paid to a separation method for gases and liquids, which involves thermal diffusion and syphon action. In particular, the experiments of Clusius and Dickel ${ }^{1}$ with carbon dioxide - hydrogen, and bromine - helium mixtures may be mentioned, while promising results in the separation of isotopes have also been reported 2 . Further, the same method gives good separations with aqueous solutions of inorganic salts ${ }^{3}$ and mixtures of organic liquids 4 .

Simple apparatus for illustrating these separations in the case of solutions has been constructed as follows. The solutions were enclosed by means of short rubber tubes within the vertical annular space between two concentric glass tubes. The diameter of the inner tube was $7 \mathrm{~mm}$., its length $150 \mathrm{~cm}$., and the annular space $0.5 \mathrm{~mm}$. in thickness. Cold water was passed through the inner tube and steam through a surrounding jacket. With a solution of copper sulphate containing $330 \mathrm{gm}$. per litre, almost complete disappearance of the blue colour, indicating, therefore, a marked reduction in concentration, was observed at the top of the apparatus after eight hours treatment, while increase in concentration was sufficient to induce crystallization at the bottom of the tube.

A second apparatus, in which the annular space was only a few tenths of a millimetre in thickness, gave rapid separations with copper bromide and with cobalt chloride. The former is brown in concentrated and greenish blue in dilute solution, while the latter gives a blue colour in moderately concentrated hydrochloric acid which, on dilution, reverts to the characteristic pink. With initial solutions of intermediate tint, the anticipated colour changes clearly developed in the upper and lower sections of the tube in each case within two to three hours.

\section{DUNCAN TAYLOR.}

Chemistry Department, Mowbray Ritchie.

University of Edinburgh.

2 Clusius and Dickel, Naturwiss., 26, 546 (1938).

'Clusius and Dickel, Naturwiss., 27, 148, 487 (1939); Watson, Phys. Rev., 56, 703 (1939).

${ }^{3}$ Clusius and Dickel, loc. cit. in 2.

${ }^{4}$ Korsching and Wirtz, Naturwiss., 27, 110 (1939).

\section{Sirius and the Constellation of the Bow}

There is rather a remarkable coincidence (if it is a coincidence) in connexion with the ancient constellation figures to the south-east of Sirius, occurring in Babylonia, China and Egypt.

In the Chinese "Star Classic", reputedly of the third or fourth century B.c., but reassembled in the ninth century A.D., there is the phrase "The Bow and Arrow are nine stars to the south east of the Wolf" (the Wolf is Sirius) ${ }^{1}$. Schlegel shows in his diagram the arrow pointing towards Sirius, which might even be regarded as the tip of the arrow.

In Babylonia "in the late period Kaksidi [Sirius] was imagined as an arrow. Behind it stood the constellation Bow. Sirius is the shining point of the arrow; presumably one or more stars between this and the bow marked the shaft" 2

On the Denderah round 'zodiac' from the small temple on the roof of the Great Temple of Denderah, now in the Louvre, there is a figure just to the left (east) of the Cow in the Barque (Sirius) which represents the goddess Satet bearing a bow and arrow ${ }^{3}$.

17, Victoria Śt.,

Herbert Chatley.

London, S.W.1.

${ }^{1}$ Schlegel, G., "Uranographie Chinoise", 1, 430-34.

2 Burrows E. "Hymn to Ninurta as Sirius", J. Roy. Asiat. Soc.,

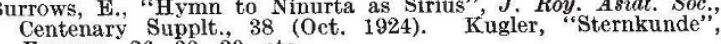
Centenary Supplt.,
Ergaenz., 26, 30, 39, etc.

a "Description de l'Egypte", Antiq., Plates, IV, Nos. 18-21. 